\title{
Convergent synthesis and light harvesting properties of dendritic boradiazaindacene (BODIPY) appended perylenediimide dyes
}

\author{
O. Altan Bozdemir, ${ }^{a}$ M. Deniz Yilmaz, ${ }^{b}$ Onur Buyukcakir, ${ }^{a}$ \\ Aleksander Siemiarczuk, ${ }^{c}$ Mehmet Tutas ${ }^{d}$ and Engin U. Akkaya*a \\ Received (in Gainesville, FL, USA) 31st July 2009, Accepted 27th September 2009 \\ First published as an Advance Article on the web 3rd November 2009 \\ DOI: $10.1039 / b 9 n j 00380 k$
}

\begin{abstract}
A convergent synthesis methodology, together with "click-chemistry" between azides and terminal alkynes, allows straighforward access to dendritic light harvesting systems. The novel dendrimer reported in this study has eight boradiazaindacene (BODIPY) units at the periphery and a perylenediimide (PDI) dye at the core. We have demonstrated that visible light is effectively collected as a result of the large absorption cross section of the dendrimer and efficiently channeled to the core PDI unit, resulting in a significant antenna effect. While being one of the very few energy transfer systems with a BODIPY and PDI chromophore pair, this novel dendritic molecule is one of the most efficient in light harvesting. The factors that may play important roles as the generation number increases also become apparent when emission characteristics were analyzed in comparison with a lower generation dendrimer.
\end{abstract}

\section{Introduction}

The photosynthetic reaction centre (PRC) is a source of inspiration for many chemists, in terms of efficiency and implementation of light harvesting. Here, a large number of chlorophyll-type and other (caratenoid or tetrapyrrolic) pigment molecules act as antenna and channel the collected photonic energy to a special dimeric arrangement of chlorophyll molecules known as the special pair. This event is mimicked in chemical systems by artificial light harvesting systems. In such systems, organizing a large number of chromophores around an energy acceptor is most effectively realized by a dendritic structure. In recent years, a number of skillfully designed examples of dendritic light harvesting systems (LHS) have appeared in the literature. ${ }^{1}$ We are particularly interested in the synthesis of such structures by making use of the "click-chemistry" version $^{2}$ of the well-known Huisgen reaction.

As the donor-acceptor chromophore pair, we prefer boradiazaindacene (BODIPY) and perylenediimide dyes, as we have already demonstrated that very efficient energy transfer is possible within this pair. ${ }^{1 f}$ Boradiazaindacenes are well known, ${ }^{3}$ bright green-emitting fluorescent dyes with many diverse applications, such as fluorescent labeling of biomolecules, ${ }^{4}$ efficient sensitizers for photodynamic therapy, ${ }^{5}$ ion sensing and signaling, ${ }^{6}$ energy transfer cassettes, ${ }^{7}$ light harvesting systems. ${ }^{1 f, 8}$ and supramolecular polymers. ${ }^{9}$ The parent dye absorbs near $480 \mathrm{~nm}$ and emits around $490 \mathrm{~nm}$, but it is

\footnotetext{
${ }^{a}$ Department of Chemistry and UNAM-Institute of Material Science and Nanotechnology, Bilkent University, 06800 Ankara, Turkey.

E-mail: eua@fen.bilkent.edu.tr; Fax: +90 312266 4068;

Tel: + 903122902450

${ }^{b}$ Department of Chemistry, Middle East Technical University, 06531 Ankara, Turkey

${ }^{c}$ PTI Fast Kinetics Laboratory, 347 Consortium Court, London, Ontario, N6E 2S8, Canada

${ }^{d}$ Department of Chemistry, Faculty of Arts and Science, Akdeniz University, Antalya, 07058, Turkey
}

amenable to modifications, ${ }^{7 c, 10}$ through which the absorption and the emission peaks can be shifted to the red end of the visible spectrum.

Through-space energy transfer efficiency is primarily controlled by two parameters, (1) the distance between the energy donor and acceptor chromophores, and (2) the spectral overlap between the emission spectrum of the energy donor and the absorption spectrum of the energy acceptor. Considering the spectral characteristics of the BODIPY dyes and the bay region-substituted perylenediimide dyes which have typical absorption peaks around $580 \mathrm{~nm}$, we targeted two different dendritic BODIPY-substituted PDI dyes (7 and 11). In this design, it is obvious that the peripheral chromophores are to act as antenna with very large cumulative absorption cross sections. In the synthesis scheme shown in Scheme 1, the key intermediates are azidoboradiazaindacene derivative $\mathbf{3}$, and the tetra-alkynyl-substituted PDI 6. The click reactions were carried out in a solvent mixture composed of $\mathrm{CHCl}_{3}$ EtOH-water. The octaboradiazaindacene-substituted compound 11 was synthesized by making use of a Frechet style convergent approach. ${ }^{11}$ Thus, the two boradiazaindacene dyes were first tethered to a disubstituted benzylbromide $\mathbf{8}$, and then converted to an azide and carried over to the final "click" step, yielding the two dendritic light harvesting molecules.

\section{Results and discussion}

In comparing the absorption spectra of compounds 7 and 11 (Fig. 1), it is clear that increasing the number of boradiazaindacene peripheral units from 4 to 8 results in a larger total extinction coefficient at $520 \mathrm{~nm}$. The increase is not exactly 2 -fold, but close to $60 \%$. This can be taken as evidence for interchromophoric interactions between the BODIPY units. There is also a small hypsochromic shift $(-3 \mathrm{~nm})$ in the absorption spectrum of $\mathbf{1 1}$ compared to $\mathbf{7}$ which may support this conclusion. 


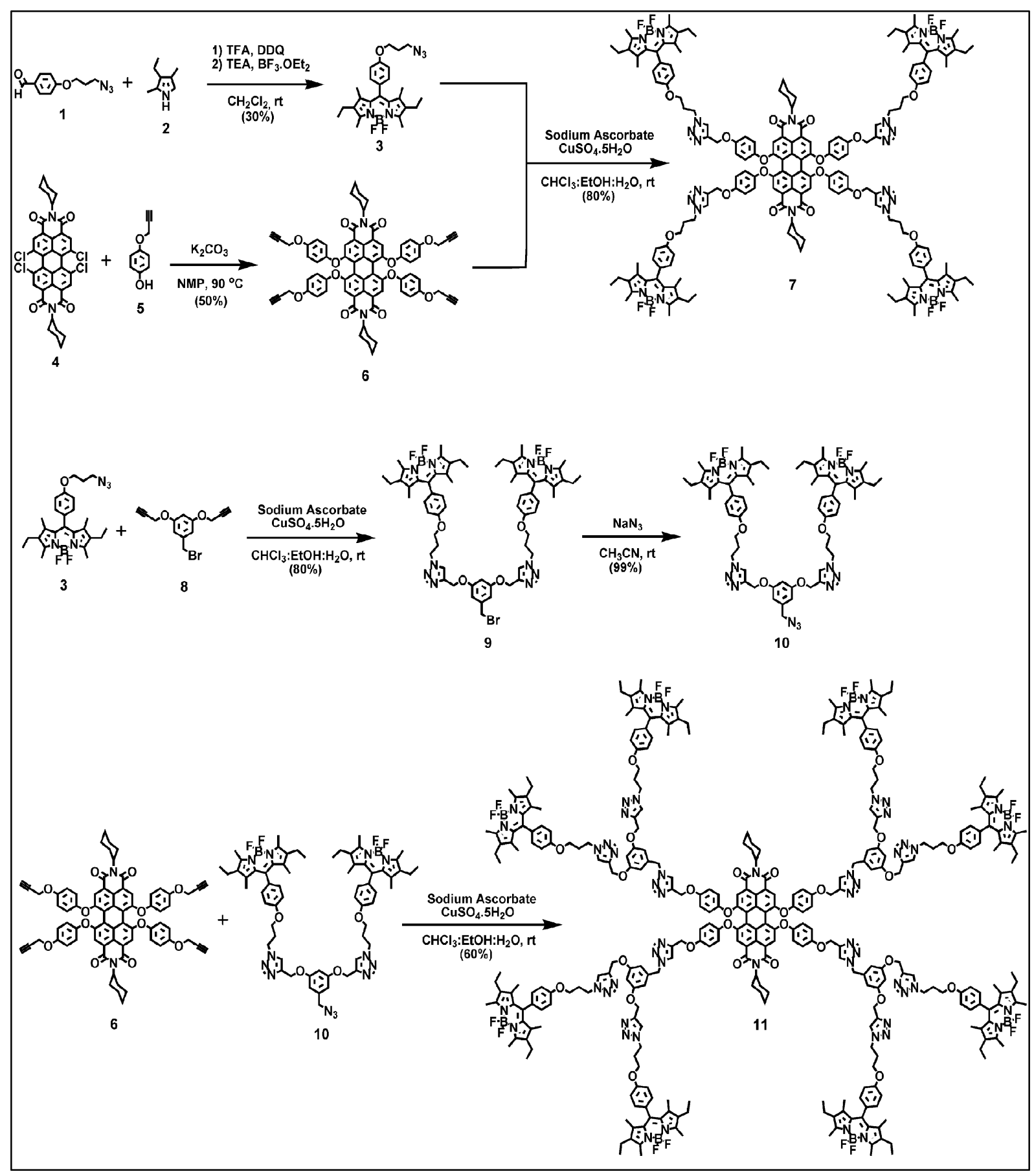

Scheme 1 Synthesis of the novel light harvesting systems.

The emission spectra (Fig. 2) are more revealing; for an effective comparison, $\mathrm{CHCl}_{3}$ solutions of equal absorbance at $588 \mathrm{~nm}$ (corresponding to the absorption peak of the PDI core) were prepared.

Excitation of a solution of the reference boradiazaindacene 3 at $526 \mathrm{~nm}$ (boradiazaindacene absorption peak) yields a very strong emission at around $538 \mathrm{~nm}$. When a solution of the dendrimer 11, having the same absorption at $526 \mathrm{~nm}$, was excited, very weak emission (almost at the baseline level) from boradiazaindacene chromophores was observed. This is in accordance with the proposed energy transfer scheme.
Time-resolved fluorescence spectroscopy provides solid evidence for the energy transfer: the reference BODIPY dye $\mathbf{3}$ has an emission lifetime of $4.26 \mathrm{~ns}$ (Table 1). The residual emission of the energy donor BODIPY units in compounds $\mathbf{7}$ and $\mathbf{1 1}$ have emission lifetimes of 0.05 and $0.11 \mathrm{~ns}$, respectively, indicating a fast energy transfer. The energy transfer rates $\left(k_{\mathrm{ET}}\right)$ were calculated for compounds $\mathbf{7}$ and $\mathbf{1 1}$ and the values are $1.77 \times 10^{10}$ and $6.77 \times 10^{9} \mathrm{~s}^{-1}$, respectively. ${ }^{8 d}$ Thus, an energy transfer efficiency of $98.7 \%$ was calculated for 7 , and $95.7 \%$ for the larger dendritic light harvester, 11. ${ }^{12}$ On the other hand, the emission intensity at $615 \mathrm{~nm}$ (PDI core emission) is 


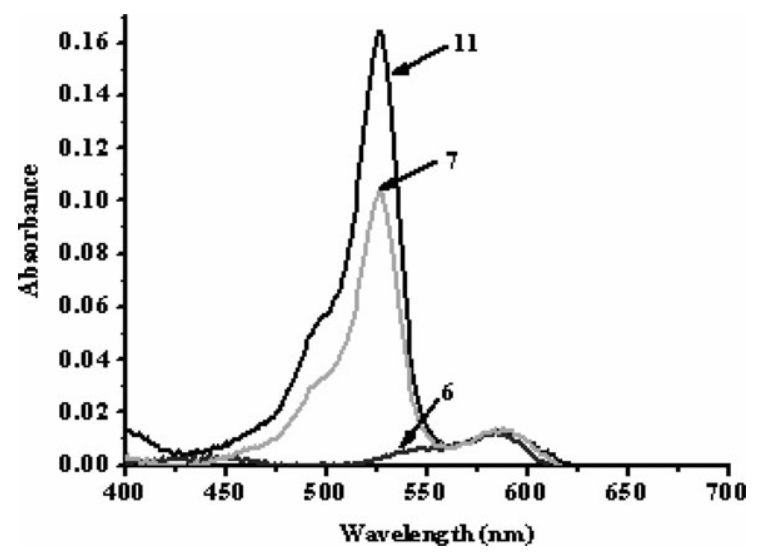

Fig. 1 Absorbance spectra of compounds 6, 7 and 11 at equal absorbances at $588 \mathrm{~nm}$ in $\mathrm{CHCl}_{3}$.

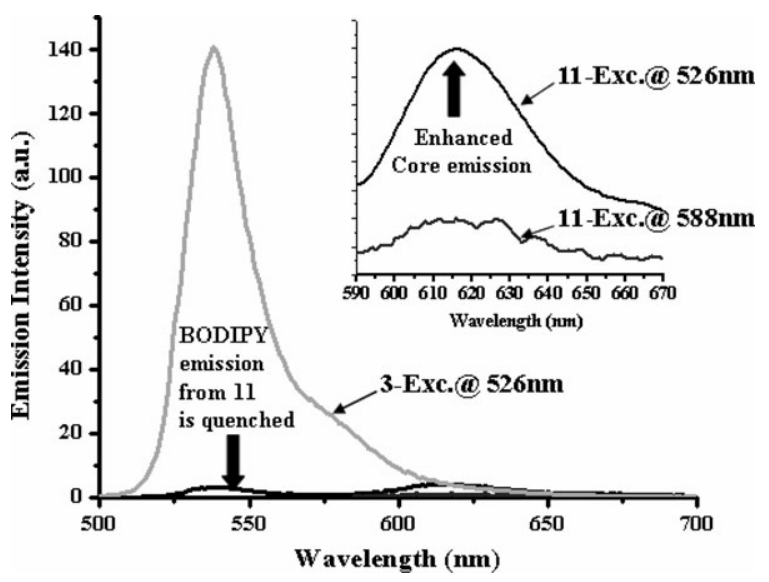

Fig. 2 The emission spectra of $\mathbf{3}$ and $\mathbf{1 1}$ at equal absorbances at $526 \mathrm{~nm}$ in $\mathrm{CHCl}_{3}$. Inset: enhanced core emission on excitation of the peripheral BODIPY units in the light-harvesting molecule $\mathbf{1 1 .}$

enhanced 4-fold when compound $\mathbf{1 1}$ is excited at $526 \mathrm{~nm}$ as opposed to $590 \mathrm{~nm}$. This is a satisfactory demonstration of the antenna effect. A similar study with compound 7 resulted in a smaller antenna effect, giving a 3.5 -fold enhancement. ${ }^{1 f}$ The emissions from the PDI core have comparable lifetimes in the dendritic molecules $\mathbf{7}$ and $\mathbf{1 1}$ and the reference PDI derivative 6, ranging from 4.95 to 5.57 ns. In compound 11, the Förster radius $\left(R_{\mathrm{o}}\right)$ was calculated as $62 \AA$, and the average donoracceptor distance based on the energy-minimized structure of 11 was determined to be $36 \AA$. This is well within the Förster radius, so efficient energy transfer is to be expected. The differences between compounds $\mathbf{7}$ and $\mathbf{1 1}$ are instructive: in dendritic molecule 7, the donor and acceptor chromophores are in close proximity, and, as a result, the energy transfer is somewhat more efficient. Not surprisingly, in 11, some residual BODIPY emission is present. This may be due, at least in part, to the increased distance between the boradiazaindacene and PDI chromophores. One important result is that although the average distance between the antenna chromophores increases on going from $\mathbf{7}$ to 11, the efficiency does not decrease significantly and there is a modest increase in the antenna effect.
Table 1 Spectral parameters for the compounds studied: absorption wavelength $\left(\lambda_{\text {abs }}\right)$, extinction coefficient $\left(\varepsilon_{\max }\right)$, emission wavelength $\left(\lambda_{\text {ems }}\right)$, emission lifetime $(\tau)$, quantum yield $(\Phi)^{a}$

\begin{tabular}{llllllll}
\hline & $\lambda_{\text {abs }} / \mathrm{nm}$ & $\varepsilon_{\text {max }} / \mathrm{M}^{-1} \mathrm{~cm}^{-1}$ & $\lambda_{\text {ems }} / \mathrm{nm}$ & $\tau / \mathrm{ns}$ & $\lambda_{\mathrm{ems}} / \mathrm{nm}$ & $\tau / \mathrm{ns}$ & $\Phi^{b}$ \\
\hline $\mathbf{7}$ & 526 & 240000 & 540 & 0.05 & 616 & 4.95 & 0.60 \\
& 590 & 45000 & & & & & \\
$\mathbf{1 1}$ & 526 & 408000 & 540 & 0.11 & 616 & 5.57 & 0.67 \\
& 590 & 45000 & & & & & \\
$\mathbf{3}$ & 526 & 62000 & 540 & 4.26 & & & \\
$\mathbf{6}$ & 590 & 45700 & & & 616 & 5.40 & 0.27 \\
${ }^{a}$ Determined in $\mathrm{CHCl}_{3}$ solution. ${ }^{b}$ Rhodamine $6 \mathrm{G}$ in ethanol $\left(\Phi_{\mathrm{f}}=0.95\right)$ \\
was used as reference.
\end{tabular}

\section{Conclusions}

In building large dendritic systems for efficient light harvesting, inevitably, the distance between the peripheral chromophores and the core increases. While the absorption cross-section increases with increasing generation number, the efficiency of energy transfer tends to decrease. However, with judicious design, if the spectral overlap between the energy donor chromophores and the energy acceptor core is large enough, increased distance can be tolerated. It is clear that BODIPY and tetraaryloxyperilendiimide dyes are a very good match in this regard. Dendritic designs using this pair are very likely to succeed. One can even envision energy cascade systems, where intervening chromophores concentrate and channel the excitation energy to the core chromophore(s). The versatile chemistry of BODIPY is expected to yield such light harvesting systems with highly directional energy transfer. In fact, the earliest examples of such BODIPY-based systems have already appeared in the literature. ${ }^{7,8}$ Their potential in solar light harvesting is also beginning to be appreciated. Our work along these lines is in progress.

\section{Experimental}

\section{General}

The compounds were characterized and analyzed by nuclear magnetic resonance (NMR) spectroscopy, UV/Vis spectroscopy, and fluorescence spectroscopy. ${ }^{1} \mathrm{H}$ and ${ }^{13} \mathrm{C}$ NMR spectra of all compounds were recorded in $\mathrm{CDCl}_{3}$ with a Bruker Gmbh DPX-400, $400 \mathrm{MHz}$ high performance digital FT-NMR spectrometer. UV/Vis spectra were recorded with a Varian Bio $100 \mathrm{UV} /$ Vis spectrophotometer. Fluorescence spectra were recorded using a Varian Cary Eclipse fluorescence spectrophotometer. The fluorescence decay measurements were carried out with the TM-3 LaserStrobe time-resolved fluorometer utilizing a pulsed nitrogen/dye laser excitation and the stroboscopic detection system. The dye laser excitation was at 526 and $590 \mathrm{~nm}$. The instrument response function was measured with an aqueous Ludox solution. The decays were analyzed with a multiexponential fitting function by iterative reconvolution and chi-square minimization. Mass spectrometry measurements were done at the Ohio State University Mass Spectrometry and Proteomics Facility, Ohio, USA, or the Kent Mass Spectrometry Laboratory, Kent, UK All solvents were distilled over $\mathrm{CaCl}_{2}$ before use. All chemicals were obtained from Aldrich, unless noted otherwise. Merck Silica 
Gel $60 \mathrm{~F}_{254}$ TLC aluminium sheets were used to monitor reactions by thin layer chromatography. Merck Silica Gel 60 (particle size 0.040-0.0963 mm, 230-400 mesh ASTM) was used in column chromatography.

\section{Syntheses}

4-(3-azidopropoxy)benzaldehyde (1). A mixture of 4-(3bromopropoxy)benzaldehyde (5.37 mmol, $1.3 \mathrm{~g}$ ) and $\mathrm{NaN}_{3}$ (13.425 mmol, $0.87 \mathrm{~g}$ ) in $20 \mathrm{ml} \mathrm{DMF}$ was heated at $100{ }^{\circ} \mathrm{C}$ overnight. The mixture was poured into water and extracted with $\mathrm{CHCl}_{3}$ several times. Removal of solvent gave the pure azide compound. Colorless oil (1.05 g, 99\%). ${ }^{1} \mathrm{H}$ NMR $\left(\mathrm{CDCl}_{3}\right): \delta(\mathrm{ppm}) 9.85(\mathrm{~s}, 1 \mathrm{H}), 7.81(\mathrm{~d}, J=8.5 \mathrm{~Hz}, 2 \mathrm{H})$, $6.98(\mathrm{~d}, J=8.5 \mathrm{~Hz}, 2 \mathrm{H}), 4.17(\mathrm{t}, J=5.8 \mathrm{~Hz}, 2 \mathrm{H}), 3.58$ $(\mathrm{t}, J=6.4 \mathrm{~Hz}, 2 \mathrm{H}), 2.00-2.15(\mathrm{~m}, 2 \mathrm{H}) .{ }^{13} \mathrm{C} \mathrm{NMR}\left(\mathrm{CDCl}_{3}\right)$ : $\delta$ (ppm) 190.6, 163.7, 131.9, 130.0, 114.7, 64.9, 48.0, 28.5. Elemental analysis: found $\mathrm{C}, 59.33 ; \mathrm{H}, 5.49 ; \mathrm{N}, 20.39$, $\mathrm{C}_{10} \mathrm{H}_{11} \mathrm{~N}_{3} \mathrm{O}_{2}$ requires $\mathrm{C}, 58.53 ; \mathrm{H}, 5.40 ; \mathrm{N}, 20.48$.

4,4-difluoro-8-(4-(3-azidopropoxy))phenyl-1,3,5,7-tetramethyl2,6-diethyl-4-bora-3a,4adiaza-s-indacene (3). 3-Ethyl-2,4dimethylpyrrole (5.26 mmol, $0.648 \mathrm{~g})$ and compound 1 (2.6 mmol, $0.533 \mathrm{~g}$ ) were dissolved in $200 \mathrm{ml}$ dry $\mathrm{CH}_{2} \mathrm{Cl}_{2}$ (argon gas was bubbled through $\mathrm{CH}_{2} \mathrm{Cl}_{2}$ for 30 min) under argon atmosphere. One drop of TFA was added and the solution stirred at room temperature for $4 \mathrm{~h}$. At this point, a solution of DDQ (2.6 mmol, $0.640 \mathrm{~g}$ ) in $50.0 \mathrm{ml}$ dry $\mathrm{CH}_{2} \mathrm{Cl}_{2}$ was added, stirring was continued for $30 \mathrm{~min}$ followed by the addition of $3.0 \mathrm{ml} \mathrm{Et}_{3} \mathrm{~N}$ and $3.0 \mathrm{ml} \mathrm{BF}_{3} \cdot \mathrm{OEt}_{2}$. After stirring for $30 \mathrm{~min}$, the reaction mixture was washed three times with water and dried over $\mathrm{Na}_{2} \mathrm{SO}_{4}$. The solvent was evaporated and the residue was purified by silica gel column chromatography $\left(\mathrm{CHCl}_{3}\right)$. Orange-red solid $(0.374 \mathrm{~g}, 30 \%)$. ${ }^{1} \mathrm{H} \mathrm{NMR}\left(\mathrm{CDCl}_{3}\right)$ : $\delta(\mathrm{ppm}) 7.10(\mathrm{~d}, J=8.5 \mathrm{~Hz}, 2 \mathrm{H}), 6.93(\mathrm{~d}, J=8.5 \mathrm{~Hz}, 2 \mathrm{H})$, $4.05(\mathrm{t}, J=6.4 \mathrm{~Hz}, 2 \mathrm{H}), 3.49(\mathrm{t}, J=6.8 \mathrm{~Hz}, 2 \mathrm{H}), 2.45(\mathrm{~s}, 6 \mathrm{H})$, $2.25(\mathrm{q}, J=7.5 \mathrm{~Hz}, 4 \mathrm{H}), 2.01-2.15(\mathrm{~m}, 2 \mathrm{H}), 1.27(\mathrm{~s}, 6 \mathrm{H}), 0.91$ $(\mathrm{t}, J=7.5 \mathrm{~Hz}, 6 \mathrm{H}){ }^{13} \mathrm{C} \mathrm{NMR}\left(\mathrm{CDCl}_{3}\right): \delta(\mathrm{ppm}) 158.6,153.1$, 139.7, 137.9, 132.2, 130.7, 129.1, 127.7, 114.5, 64.2, 47.8, 28.3, 16.6, 14.1, 12.0, 11.3. Elemental analysis: found $\mathrm{C}, 65.44 ; \mathrm{H}$, 6.91; N, 14.53, $\mathrm{C}_{26} \mathrm{H}_{32} \mathrm{BF}_{2} \mathrm{~N}_{5} \mathrm{O}$ requires $\mathrm{C}, 65.14 ; \mathrm{H}, 6.73$; $\mathrm{N}, 14.61$.

$N, N^{\prime}$-Dicyclohexyl-1,6,7,12-tetra(4-propargyloxyphenoxy) perylene-tetracarboxylic diimide (6). A mixture of $N, N^{\prime}$-dicyclohexyl-1,6,7,12-tetrachloro-perylene-3,4,9,10-tetracarboxylic acid diimide 4 (0.72 mmol, $0.500 \mathrm{~g})$, 4-propargyloxyphenol 5 $(6.75 \mathrm{mmol}, 1.0 \mathrm{~g})$ and $\mathrm{K}_{2} \mathrm{CO}_{3}(7.25 \mathrm{mmol}, 1.0 \mathrm{~g})$ in $20 \mathrm{ml}$ NMP was heated at $90{ }^{\circ} \mathrm{C}$ overnight. A cooled mixture was poured into $20 \mathrm{ml} \mathrm{10 \%} \mathrm{HCl}$ solution, filtered with suction, and washed three times with water. The resulting precipitate was purified by column chromatography on silica gel (first $\mathrm{CHCl}_{3}$, then $\mathrm{CHCl}_{3}$-hexane, $\left.(5: 1)\right)$. Red solid $(0.410 \mathrm{~g}, 50 \%)$.

${ }^{1} \mathrm{H} \mathrm{NMR}\left(\mathrm{CDCl}_{3}\right): \delta(\mathrm{ppm}) 8.01(\mathrm{~s}, 4 \mathrm{H}), 6.85(\mathrm{~s}, 16 \mathrm{H}), 4.86$ $(\mathrm{m}, 2 \mathrm{H}), 4.63(\mathrm{~s}, 8 \mathrm{H}), 2.55(\mathrm{~s}, 4 \mathrm{H}), 1.01-2.09(\mathrm{~m}, 20 \mathrm{H}){ }^{13} \mathrm{C}$ NMR $\left(\mathrm{CDCl}_{3}\right): \delta(\mathrm{ppm}) 163.7,156.2,154.4,149.4,132.7$, 123.0, 121.1, 119.9, 119.3, 119.1, 116.4, 78.4, 75.7, 56.4, 53.9, 29.1, 26.5, 25.4 Elemental analysis: found C, 75.69; H, 4.68; N, 2.34, $\mathrm{C}_{72} \mathrm{H}_{54} \mathrm{~N}_{2} \mathrm{O}_{2}$ requires $\mathrm{C}, 75.91 ; \mathrm{H}, 4.78 ; \mathrm{N}, 2.46$. MS (MALDI) $1138.4\left(\mathrm{M}^{+}\right)$.

\section{Light harvesting molecule 7}

A solution of the compound $3(0.225 \mathrm{mmol}, 0.108 \mathrm{~g})$, compound $6(0.0535 \mathrm{mmol}, 0.061 \mathrm{~g})$, sodium ascorbate $(0.0225 \mathrm{mmol}, 0.0045 \mathrm{~g})$, and $\mathrm{CuSO}_{4}(0.01125 \mathrm{mmol}, 0.0028 \mathrm{~g})$ in a $12: 1: 1$ mixture of $\mathrm{CHCl}_{3}, \mathrm{EtOH}$ and water $(14.0 \mathrm{ml})$ was stirred at room temperature for $72 \mathrm{~h}$. The solvents were removed under reduced pressure and the crude product was purified by column chromatography $\left(\mathrm{CHCl}_{3}\right)$. Red solid (0.1309 g, 80\%).

${ }^{1} \mathrm{H} \mathrm{NMR}\left(\mathrm{CDCl}_{3}\right): \delta(\mathrm{ppm}) 8.00(\mathrm{~s}, 4 \mathrm{H}), 7.65$ (s, 4H), 7.12 $(\mathrm{d}, J=8.4 \mathrm{~Hz}, 8 \mathrm{H}), 6.93(\mathrm{~d}, J=8.5 \mathrm{~Hz}, 8 \mathrm{H}), 6.81(\mathrm{~s}, 16 \mathrm{H})$, $5.12(\mathrm{~s}, 8 \mathrm{H}), 4.86-4.95(\mathrm{~m}, 2 \mathrm{H}), 4.65(\mathrm{t}, J=6.6 \mathrm{~Hz}, 8 \mathrm{H}), 4.03$ $(\mathrm{t}, J=5.8 \mathrm{~Hz}, 8 \mathrm{H}), 2.42(\mathrm{~s}, 24 \mathrm{H}), 2.27(\mathrm{q}, J=7.5 \mathrm{~Hz}, 16 \mathrm{H})$, $1.00-2.01(\mathrm{~m}, 52 \mathrm{H}), 0.95(\mathrm{t}, J=7.5 \mathrm{~Hz}, 24 \mathrm{H}){ }^{13} \mathrm{C} \mathrm{NMR}$ $\left(\mathrm{CDCl}_{3}\right): \delta(\mathrm{ppm}) 163.7,158.9,156.4,155.2,153.6,149.1$, $144.1,139.9,138.3,132.7,131.1,129.6,128.4,123.1,122.9$, 121.4, 119.8, 119.0, 117.1, 116.1, 114.9, 64.4, 62.6, 47.3, 30.0, $29.1,26.5,21.8,17.0,14.5,12.4,11.8$. MS (MALDI) $m / z=$ $3036.4(\mathrm{M}-\mathrm{F})^{+}$.

\section{Compound 9}

A solution of the compound $3(0.626 \mathrm{mmol}, 0.300 \mathrm{~g})$, compound $8(0.313 \mathrm{mmol}, 0.0873 \mathrm{~g})$, sodium ascorbate (0.0626 mmol, $0.0124 \mathrm{~g})$, and $\mathrm{CuSO}_{4}(0.0313 \mathrm{mmol}, 0.0078 \mathrm{~g})$ in a $12: 1: 1$ mixture of $\mathrm{CHCl}_{3}, \mathrm{EtOH}$ and water $(42.0 \mathrm{ml})$ was stirred at room temperature for $72 \mathrm{~h}$. The solvents were removed under reduced pressure and the crude product was purified by column chromatography $\left(3 \% \mathrm{CHCl}_{3}-\mathrm{MeOH}\right)$. Orange-red solid $(0.155 \mathrm{~g}, 40 \%)$

${ }^{1} \mathrm{H}$ NMR $\left(\mathrm{CDCl}_{3}\right): \delta(\mathrm{ppm}) 7.56(\mathrm{~s}, 2 \mathrm{H}), 7.11(\mathrm{~d}, J=8.5$ $\mathrm{Hz}, 4 \mathrm{H}), 6.92(\mathrm{~d}, J=8.4 \mathrm{~Hz}, 4 \mathrm{H}), 6.56(\mathrm{~s}, 2 \mathrm{H}), 6.49(\mathrm{~s}, 1 \mathrm{H})$, $5.08(\mathrm{~s}, 4 \mathrm{H}), 4.62(\mathrm{t}, J=6.2 \mathrm{~Hz}, 4 \mathrm{H}), 4.35(\mathrm{~s}, 2 \mathrm{H}), 4.02(\mathrm{t}, J=$ $4.0 \mathrm{~Hz}, 4 \mathrm{H}), 2.44$ (s, 12H), 2.37 (p, $J=7.4 \mathrm{~Hz}, 4 \mathrm{H}), 2.22$ $(\mathrm{q}, J=7.5 \mathrm{~Hz}, 8 \mathrm{H}), 1.24(\mathrm{~s}, 12 \mathrm{H}), 0.95(\mathrm{t}, J=7.5 \mathrm{~Hz}, 12 \mathrm{H})$ ${ }^{13} \mathrm{C} \mathrm{NMR}\left(\mathrm{CDCl}_{3}\right): \delta(\mathrm{ppm}) 159.5,158.8,153.6,143.7,140.0$, $138.3,132.7,131.1,129.6,128.4,123.1,114.9,108.4,102.1$, $64.3,62.1,47.2,33.2,29.9,17.0,14.5,12.4,11.8$.

\section{Precursor 10}

A mixture of compound $9(0.121 \mathrm{mmol}, 0.150 \mathrm{~g})$ and $\mathrm{NaN}_{3}$ $(0.15 \mathrm{mmol}, 0.0097 \mathrm{~g})$ in $20.0 \mathrm{ml} \mathrm{CH} \mathrm{CH}_{3} \mathrm{CN}$ was stirred at room temperature overnight. The mixture was extracted with chloroform three times. Removal of solvent gave the pure azide compound.

${ }^{1} \mathrm{H} \mathrm{NMR}\left(\mathrm{CDCl}_{3}\right): \delta(\mathrm{ppm}) 7.56(\mathrm{~s}, 2 \mathrm{H}), 7.11(\mathrm{~d}, J=8.3$ $\mathrm{Hz}, 4 \mathrm{H}), 6.92(\mathrm{~d}, J=7.8 \mathrm{~Hz}, 4 \mathrm{H}), 6.54(\mathrm{~s}, 1 \mathrm{H}), 6.49(\mathrm{~s}, 2 \mathrm{H})$, $5.10(\mathrm{~s}, 4 \mathrm{H}), 4.55(\mathrm{t}, J=6.6 \mathrm{~Hz}, 4 \mathrm{H}), 4.17(\mathrm{~s}, 2 \mathrm{H}), 3.97(\mathrm{t}, J=$ $6.8 \mathrm{~Hz}, 4 \mathrm{H}), 2.44$ (s, 12H), 2.37 (p, $J=7.4 \mathrm{~Hz}, 4 \mathrm{H}), 2.22$ $(\mathrm{q}, J=7.5 \mathrm{~Hz}, 8 \mathrm{H}), 1.24(\mathrm{~s}, 12 \mathrm{H}), 0.95(\mathrm{t}, 12 \mathrm{H}){ }^{13} \mathrm{C} \mathrm{NMR}$ $\left(\mathrm{CDCl}_{3}\right): \delta(\mathrm{ppm}) 159.7,158.9,153.5,143.7,140.0,138.3$, $132.7,131.1,129.6,128.4,123.2,114.9,107.4,101.7,64.3$, $62.1,54.6,47.2,29.6,17.0,14.5,12.4,11.8$.

\section{Dendrimer 11}

A solution of the compound $6(0.0263 \mathrm{mmol}, 0.030 \mathrm{~g})$, compound $10(0.105 \mathrm{mmol}, 0.1232 \mathrm{~g})$, sodium ascorbate $(0.0105 \mathrm{mmol}, 0.0021 \mathrm{~g})$, and $\mathrm{CuSO}_{4}(0.00525 \mathrm{mmol}, 0.0013 \mathrm{~g})$ in a $12: 1: 1$ mixture of $\mathrm{CHCl}_{3}, \mathrm{EtOH}$ and water $(28.0 \mathrm{ml})$ was 
stirred at room temperature for $72 \mathrm{~h}$. The solvents were removed under reduced pressure and the crude product was purified by column chromatography $\left(3 \% \mathrm{CHCl}_{3}-\mathrm{MeOH}\right)$. Red solid $(0.0937 \mathrm{~g}, 60 \%) .{ }^{1} \mathrm{H}$ NMR $\left(\mathrm{CDCl}_{3}\right): \delta(\mathrm{ppm}) 8.00$ $(\mathrm{s}, 4 \mathrm{H}), 7.64(\mathrm{~s}, 12 \mathrm{H}), 7.12(\mathrm{~d}, J=8.3 \mathrm{~Hz}, 16 \mathrm{H}), 6.92(\mathrm{~d}, J=$ $8.5 \mathrm{~Hz}, 16 \mathrm{H}), 6.82(\mathrm{~s}, 16 \mathrm{H}), 6.54(\mathrm{~s}, 1 \mathrm{H}), 6.47(\mathrm{~s}, 2 \mathrm{H}), 5.38$ $(\mathrm{s}, 8 \mathrm{H}), 5.06(\mathrm{~s}, 24 \mathrm{H}), 4.65(\mathrm{t}, J=6.4 \mathrm{~Hz}, 16 \mathrm{H}), 4.02(\mathrm{t}, J=$ $6.6 \mathrm{~Hz}, 16 \mathrm{H}), 2.42$ (s, 48H), 2.37 (p, $J=7.4 \mathrm{~Hz}, 16 \mathrm{H}), 2.22$ (q, $J=7.4 \mathrm{~Hz}, 32 \mathrm{H}), 1.24(\mathrm{~s}, 48 \mathrm{H}), 0.91(\mathrm{t}, J=7.5 \mathrm{~Hz}, 48 \mathrm{H})$. MS (MALDI) $m / z=6039.5(\mathrm{M}-\mathrm{F}+3 \mathrm{~K})^{+}$.

\section{Acknowledgements}

The authors gratefully acknowledge partial support from Turkish Academy of Sciences (TUBA) and Akdeniz University.

\section{References}

1 (a) A. Adronov and J. M. J. Frechet, Chem. Commun., 2000, 1701-1710; (b) V. Balzani, P. Ceroni, M. Maestri and V. Vicinelli, Curr. Opin. Chem. Biol., 2003, 7, 657-665; (c) A. P. H. J. Schenning, E. Peeters and E. W. Meijer, J. Am. Chem. Soc., 2000, 122, 4489-4495; (d) K. R. J. Thomas, A. L. Thompson, A. V. Sivakumar, C. J. Bardeen and S. Thayumanavan, J. Am. Chem. Soc., 2005, 127, 373-383; (e) S. Wang, J. W. Hong and G. C. Bazan, Org. Lett., 2005, 7, 1907-1910; $(f)$ W. R. Dichtel, S. Hecht and J. M. J. Frechet, Org. Lett., 2005, 7, 4451-4454; (g) M. D. Yilmaz, O. A. Bozdemir and E. U. Akkaya, Org. Lett., 2006, 8, 2871-2873; (h) A. Nantalaksakul, R. R. Dasari, T.-S. Ahn, R. Al-Kaysi, C. J. Bardeen and S. Thayumanavan, Org. Lett., 2006, 8, 2981-2984; (i) M. Takahashi, H. Morimoto, K. Miyake, H. Kawai, Y. Sei, K. Yamaguchi, T. Senguko and H. Yoda, New J. Chem., 2008, 32, 547-553; (j) A. Nantalaksakul, A. Mualler, A. Klaikherd, C. J. Bardeen and S. Thayumanavan, J. Am. Chem. Soc., 2009, 131, 2727-2728.

2 (a) C. W. Tornøe, C. Christensen and M. Meidal, J. Org. Chem., 2002, 67, 3057-3064; (b) V. V. Rostovtsev, L. G. Green, V. V. Fokin and K. B. Sharpless, Angew. Chem., Int. Ed., 2002, 41, 2596-2599.

3 Handbook of Fluorescent Probes and Research Products, R. P. Haugland, Molecular Probes, Inc., Eugene, OR, 9th edn, 2003.

4 (a) M. Yee, S. C. Fas, M. Stohlmeyer, T. J. M. Wandless and K. A. Cimprich, J. Biol. Chem., 2005, 280, 29053-29059; (b) K. Tan, L. Jaquinod, R. Paolesse, S. Nardis, C. Di Natale, A. Di Carlo, L. Prodi, M. Montalti, N. Zaccheroni and K. M. Smith, Tetrahedron, 2004, 60, 1099-1106.

5 (a) S. Atilgan, Z. Ekmekci, A. L. Dogan, D. Guc and E. U. Akkaya, Chem. Commun., 2006, 4398-4400; (b) S. Ozlem and E. U. Akkaya, J. Am. Chem. Soc., 2009, 131, 48-49.

6 Recent examples: (a) B. Turfan and E. U. Akkaya, Org. Lett., 2002, 4, 2857-2859; (b) G. Ulrich and R. J. Ziessel, J. Org. Chem.,
2004，69, 2070-2083; (c) Y. Gabe, Y. Urano, K. Kikuchi, H. Kojima and T. Nagano, J. Am. Chem. Soc., 2004, 126, 3357-3367; (d) K. Rurack, M. Kollmannsberger, U. Resch-Genger and J. Daub, J. Am. Chem. Soc., 2000, 122, 968-969; (e) A. Coskun, B. T. Baytekin and E. U. Akkaya, Tetrahedron Lett., 2003, 44, 5649-5651; $(f)$ A. Coskun and E. U. Akkaya, Tetrahedron Lett., 2004, 45, 4947-4949; $(g)$ A. Coskun and E. U. Akkaya, J. Am. Chem. Soc., 2005, 127, 10464-10465; (h) A. Coskun and E. U. Akkaya, J. Am. Chem. Soc., 2006, 128, 14474-14475.

7 (a) A. Burghart, L. H. Thoresen, J. Chen, K. Burgess, F. Bergstrom and L. B.-A. Johansson, Chem. Commun., 2000, 2203-2204; (b) C.-W. Wan, A. Burghart, J. Chen, F. Bergström, L. B.-A. Johansson, M. F. Wolford, T. G. Kim, M. R. Topp, R. M. Hochstrasser and K. Burgess, Chem.-Eur. J., 2003, 9, 4430-4441; (c) G. Ulrich, C. Goze, M. Guardigli, A. Roda and R. Ziessel, Angew. Chem., Int. Ed., 2005, 44, 3694-3698; (d) A. Harriman, L. Mallon and R. Ziessel, Chem.-Eur. J., 2008, 14, 11461-11473; (e) S. Diring, F. Puntoriero, F. Nastasi, S. Campagna and R. Ziessel, J. Am. Chem. Soc., 2009, 131, 6108-6110; $(f)$ A. Harriman, L. J. Mallon, S. Goeb, G. Ulrich and R. Ziessel, Chem.-Eur. J., 2009, 15, 4553-4564; (g) G. Barin, M. D. Yilmaz and E. U. Akkaya, Tetrahedron Lett., 2009, 50, $1738-1740$.

8 (a) F. Li, S. I. Yang, Y. Ciringh, J. Seth, C. H. Martin III, D. L. Singh, D. Kim, R. R. Birge, D. F. Bocian, D. Holten and J. S. Lindsey, J. Am. Chem. Soc., 1998, 120, 10001; (b) R. K. Lammi, A. Amboise, T. Balasubramanian, R. W. Wagner, D. F. Bocian, D. Holten and J. S. Lindsey, J. Am. Chem. Soc., 2000, 122, 7579; (c) A. Ambroise, C. Kirmaier, R. W. Wagner, R. S. Loewe, D. F. Bocian, D. Holten and J. S. Lindsey, J. Org. Chem., 2002, 67, 3811; (d) M. Yuan, X. Yin, H. Zheng, C. Ouyang, Z. Zuo, H. Liu and Y. Li, Chem.-Asian J., 2009, 4, 707-713.

9 O. A. Bozdemir, O. Buyukcakir and E. U. Akkaya, Chem.-Eur. J., 2009, 15, 3830-3838.

10 (a) C. Goze, G. Ulrich, L. J. Mallon, B. D. Allen, A. Harriman and R. Ziessel, J. Am. Chem. Soc., 2006, 128, 10231-10239; (b) R. Ziessel, C. Goze, G. Ulrich, M. Cesario, P. Retailleau, A. Harriman and J. P. Rostron, Chem.-Eur. J., 2005, 11, 7366-7378; (c) C. Goze, G. Ulrich and R. Ziessel, Org. Lett., 2006, 8, 4445-4448; (d) Z. Dost, S. Atilgan and E. U. Akkaya, Tetrahedron, 2006, 62, 8484-8488; (e) A. Coskun, E. Deniz and E. U. Akkaya, Org. Lett., 2005, 7, 5187-5189; (f) N. Saki, T. Dinc and E. U. Akkaya, Tetrahedron, 2006, 62, 2721-2725; (g) M. Baruah, W. Qin, R. A. L. Vallee, D. Beljonne, T. Rohand, W. Dehaen and N. Boens, Org. Lett., 2005, 7, 4377-4380; $(h)$ Y. Gabe, T. Ueno, Y. Urano, H. Kojima and T. Nagano, Anal. Bioanal. Chem., 2006, 386, 621-626; (i) E. Deniz, C. Isbasar, O. A. Bozdemir, T. L. Yildirim, A. Siemiarczuk and E. U. Akkaya, Org. Lett., 2008, 10, 3401-3403.

11 (a) C. J. Hawker and J. M. J. Frechet, J. Chem. Soc., Chem. Commun., 1990, 1010-1013; (b) C. J. Hawker and J. M. J. Frechet, J. Am. Chem. Soc., 1990, 112, 7638-7947.

12 R. P. Haugland, J. Yguerabide and L. Stryer, Proc. Natl. Acad. Sci. U. S. A., 1969, 63, 23-30. 